\title{
EVALUATION OF THE FREQUENCY OF TROCAR SITE HERNIA AFTER LAPAROSCOPIC SLEEVE GASTRECTOMY
}

\author{
LAPAROSKOPIK SLEEVE GASTREKTOMI AMELIYATI SONRASI TROKAR YERI HERNISI \\ GELIŞIM SIKLIĞININ ARAŞTIRILMASI
}

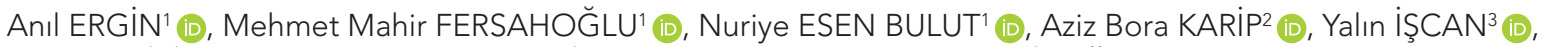

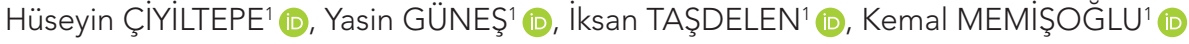 \\ ${ }^{1}$ Health Sciences University, Istanbul Fatih Sultan Mehmet Training and Research Hospital, General Surgery Clinic, Istanbul, Turkey \\ ${ }^{2}$ Istanbul Oncology Hospital, Department of General Surgery, Istanbul, Turkey \\ ${ }^{3}$ Istanbul University, Istanbul Faculty of Medicine, Department of General Surgery, Istanbul, Turkey
}

ORCID IDs of the authors: A.E. 0000-0001-6450-7124; M.M.F. 0000-0003-2526-1832; N.E.B. 0000-0002-4845-8964; A.B.K. 0000-0001-9396-6055; Y.I. 0000-0002-5576-9496; H.Ç. 0000-0003-3048-1784; Y.G. 0000-0001-5355-8321;

i.T. 0000-0001-9289-2744; K.M. 0000-0002-9486-4648

Cite this article as: Ergin A, Fersahoglu MM, Esen Bulut N, Karip AB, Iscan Y, Ciyiltepe H, et al. Evaluation of the frequency of trocar site hernia after laparoscopic sleeve gastrectomy. J Ist Faculty Med 2022;85(1):35-40. doi: 10.26650/IUITFD.947187

\section{ABSTRACT}

Objective: Today, laparoscopic sleeve gastrectomy (LSG) has become the most frequently performed bariatric surgical method. One of the complications seen after LSG is trocar site hernia (TSH). There is no clear information about the rate of TSH detected radiologically after LSG. A thick abdominal wall and the failure to adequately expose the fascial defect related to this, as well as mobility limitations due to excessive subcutaneous fatty tissue, are the reasons for increased incidence of TSH.

Materials and Methods: The demographic characteristics and postoperative weight loss of patients who underwent LSG procedures and whose fascial defects in the trocar region were repaired with the Carter-Thomason Suture Passer (CTSP) in our clinic between January 2015 and June 2017 were evaluated. TSH evaluation was performed both through physical examination and superficial USG by a general surgeon who had radiological training on concurrent superficial abdominal ultrasonography (USG). Detected TSHs were divided into two groups: symptomatic and asymptomatic.

Results: A total of 61 patients were included in the study. The mean period after operation was calculated as 36 months (min 20, max 52). TSH was detected in seven (11.5\%) of 61 patients, two of whom had symptomatic and five of whom had asymptomatic TSH. Being over 40 years of age and having a calculated body mass index (BMI) value greater than $30 \mathrm{~kg} / \mathrm{m}^{2}$ during measurement were found to be the factors that significantly increased the incidence of TSH $(p<0.05)$.

\section{ÖZET}

Amaç: Günümüzde laparoskopik sleeve gastrektomi (LSG) en sık uygulanan obezite cerrahisi yöntemi haline gelmiştir. LSG sonrası görülen komplikasyonlardan biri de trokar yeri fıtığıdır (TSH). LSG sonrası radyolojik olarak saptanan TSH oranı hakkında net bir bilgi yoktur. Kalın karın duvarı ve buna bağlı fasya defektinin yeterince ortaya konulamaması, cilt altı yağ dokusunun fazla olmasına bağlı hareket kısıtıığı, TSH insidansının artmasıyla suçlanan nedenlerdir.

Gereç ve Yöntem: Ocak 2015-Haziran 2017 tarihleri arasında kliniğimizde LSG ameliyatı yapılan ve trokar bölgesindeki fasya defektleri Carter-Thomason Sütür Geçirici (CTSP) ile onarılan hastaların demografik özellikleri ve ameliyat sonrası kilo kayıpları değerlendirildi. TSH değerlendirmesi, eş zamanlı yüzeyel abdominal ultrasonografi (USG) konusunda radyolojik eğitim almış bir genel cerrah tarafindan hem fizik muayene hem de yüzeyel USG ile yapıldı. Tespit edilen TSH'ler semptomatik ve asemptomatik olmak üzere iki gruba ayrıldı.

Bulgular: Çalışmaya toplam 61 hasta dahil edildi. Ameliyat sonrası ortalama takip süresi 36 ay (min 20, max 52 ay) olarak hesaplandı. 61 hastanın yedisinde $(\% 11,5)$ TSH (ikisi semptomatik, beşi asemptomatik) saptandı. Kırk yaşın üzerinde olmak ve ölçüm sırasında hesaplanan vücut kitle indeksi (VKI) değerinin 30 $\mathrm{kg} / \mathrm{m}^{2}$ 'nin üzerinde olması TSH insidansını anlamlı olarak artıran faktörler olarak bulundu $(\mathrm{p}<0,05)$.

Sonuç: Sleeve Gastrektomi sonrası TSH oranını artıran faktörler ileri yaş ve yetersiz kilo kaybıdır.

Corresponding author/iletişim kurulacak yazar: dranilergin@gmail.com

Submitted/Başvuru: 03.06.2021 • Revision Requested/Revizyon Talebi: 04.10.2021 •

Last Revision Received/Son Revizyon: 04.10.2021 • Accepted/Kabul: 15.11.2021 • Published Online/Online Yayın: 11.01.2022 
Conclusions: Advanced age and inadequate weight loss are the factors that increase the rate of TSH after Sleeve Gastrectomy.

Keywords: Morbid obesity, laparoscopic sleeve gastrectomy, trocar site hernia, Carter-Thomason suture passer
Anahtar Kelimeler: Morbid obezite, laparoskopik sleeve gastrektomi, trokar yeri fıtığı, Carter-Thomason sütür geçirici

\section{INTRODUCTION}

The frequency of the application of laparoscopic techniques in abdominal surgery increases day by day. The main benefits of laparoscopy consist of decreased postoperative pain, rapid return to daily activities and short hospitalization time $(1,2)$. The rate of trocar site-related complications was found to be 2.1/1000 in laparoscopy (3).

The causes of trocar site hernia (TSH) include factors such as trocar size, type of trocar, pre-existing fascial defect, and aspect of trocar entry $(4,5)$. It is known that the frequency of TSH development is even higher in obese patients (6). On the other hand, no clear ratio has been determined in the literature. It is shown in the literature that obesity is associated with the increase in trocar site-related complications; long trocar need, a thick abdominal wall, and mobility limitations due to excessive subcutaneous fatty tissue are some of the reasons for this condition (7).

In this study, we aimed to determine the frequency of $\mathrm{TSH}$ and the factors affecting the development of TSH in patients whose fascial defects of $10 \mathrm{~mm}$ or more were repaired with the Carter-Thomason Suture Passer (CTSP) after laparoscopic sleeve gastrectomy (LSG).

\section{MATERIALS AND METHODS}

This study included 61 patients who applied to the obesity follow-up outpatient clinic for any complaints or routine follow-ups over a 3-month period or who were called by telephone for follow-up and who underwent laparoscopic sleeve gastrectomy for morbid obesity between January 2015 and June 2017. This study was approved by the Clinical Research Ethical Committee of the Health Sciences University, Istanbul Fatih Sultan Mehmet Training and Research Hospital (Date: 12.09.2019, No: 80).

Patients with symptoms associated with trocar site hernia were also included in the study, while patients with multiple bariatric surgical procedures or abdominal operations were excluded. Physical examinations to detect hernias were performed both in standing and supine positions for all patients and also during the application of increased abdominal pressure using the Valsalva maneuver. All abdominal incision sites were examined. On physical examination, a hernia was defined as a bulging during the Valsalva maneuver and palpation of the fascial defect. USG was performed by a clinician who had previously received superficial USG evaluation training for trocar site hernia with a GE pro 500, $3 \mathrm{MHz}$, and abdominal incision sites were investigated for the presence of hernias (Figure 1, 2).

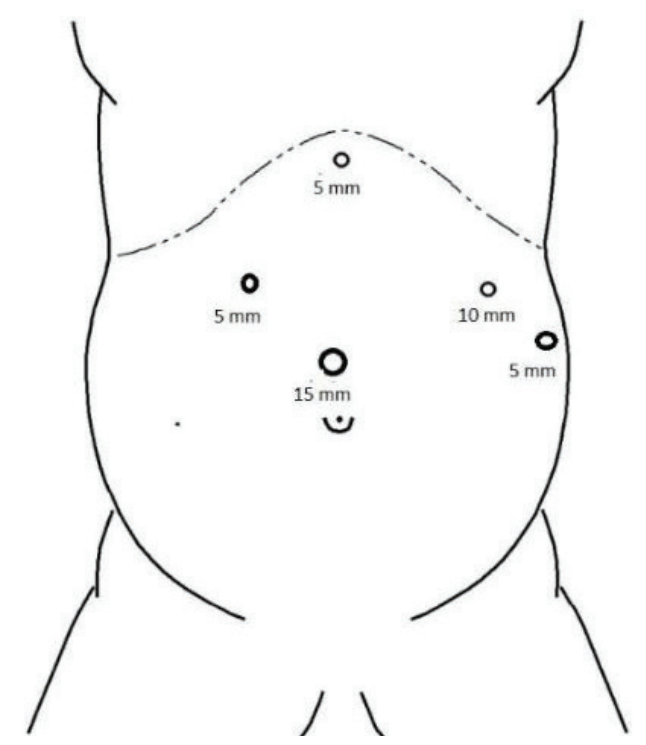

Figure 1: LSG trocar entry localizations

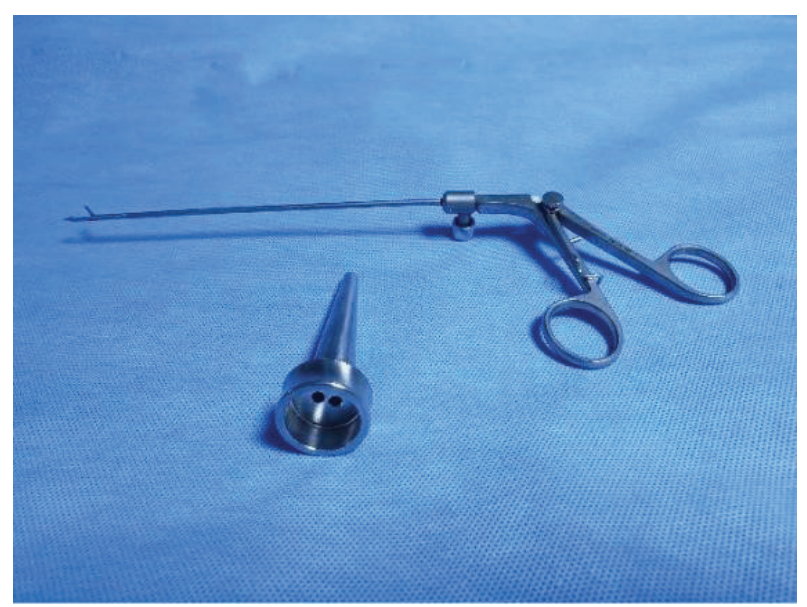

Figure 2: Carter-Thomason suture passer (CTSP)

The trocar entry localizations of the patients were all the same and are as follows: one 15-mm camera trocar (supraumbilical), one 10-mm working trocar (left upper quadrant), two 5-mm working trocars (right and left upper quadrant), and one 5-mm liver retractor. Trocar entry localizations are shown in Figure 3. During the fascia closure procedure, a No. 0 absorbable suture (PolyglactinYü-ce Vicryl®, Tekirdağ, Turkey) was used with 


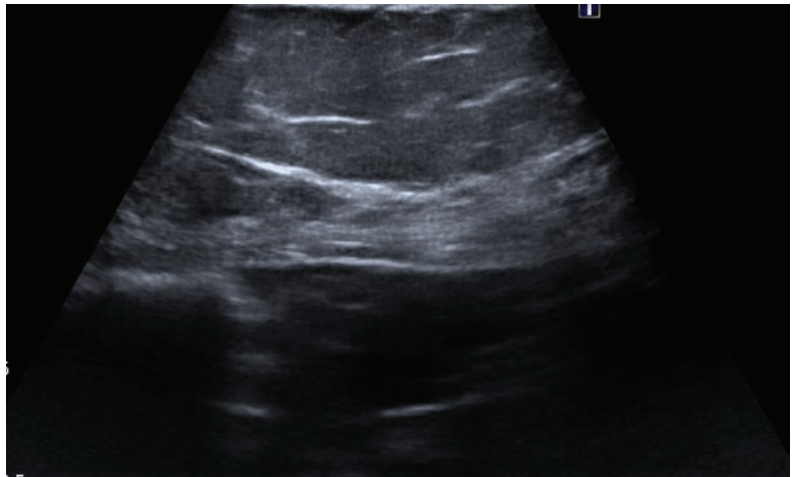

Figure 3: Normal superficial USG image from $5 \mathrm{~cm}$ superolateral to the umbilicus

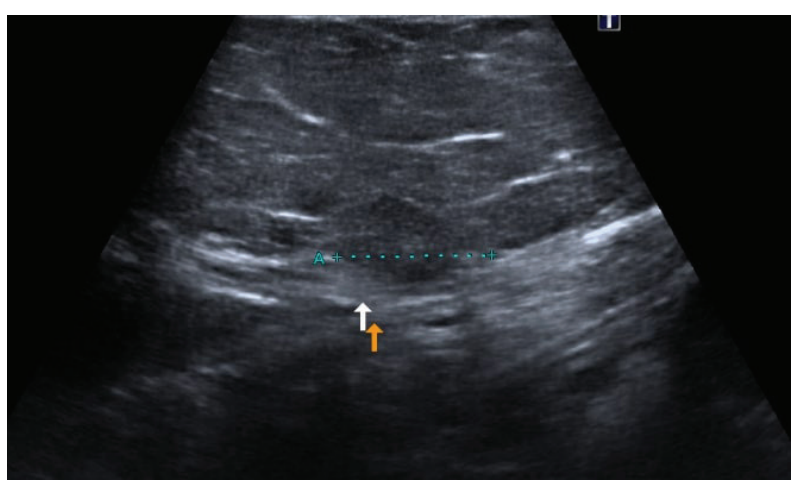

Figure 4: Superficial USG image of TSH

the CTSP (Figure 4). The 10- and 15-mm trocars were removed and a 10-mm reusable metal tube was placed in place of the trocar (Figure 4). Guided by the inserted metal tube, with the help of CTSP through the upper hole on the tube, No. 0 absorbable sutures (PolyglactinYü-ce Vicryl@, Tekirdağ, Turkey) were sent into the abdomen with camera. The metal tube with guide holes allowed the suture to advance through the fascia and peritoneum. Following this, CTSP was sent through the lower guide hole on the metal tube and the No. 0 Vicryl suture, which was advanced into the abdomen, was caught and taken out of the abdomen. The metal tube was slid out of the abdomen, taking care not to cause the suture to protrude. The suture was securely tied and the fascia closure procedure was terminated. The collected data were recorded in a pre-established database with age, gender, Diabetes Mellitus (DM), postoperative follow-up period, $\mathrm{BMI}$ at the time of operation and BMI during superficial USG.

\section{Statistical analysis}

When evaluating the findings obtained in this study, the IBM SPSS Statistics 22 (SPSS IBM, USA) program was used for statistical analysis. When evaluating the study data, the Shapiro Wilks test was used for the suitability of the parameters for normal distribution. In addition to the descriptive statistical methods (mean, standard deviation, frequency), the Student t-test was used for the twogroup comparisons of the quantitative parameters with normal distribution, and the Mann Whitney $U$ test was used for the two-group comparisons of the quantitative parameters without normal distribution. The Chi-square test and Fisher's exact test were used for the comparison of the qualitative data. The level of significance was set at $p<0.05$.

\section{RESULTS}

Between January 2015 and June 2017, a total of 61 patients ( 41 females and 20 males) aged between 21 and 64 years were included in the study. The demographic and descriptive characteristics of the cases are summarized in the table below (Table 1).

Table 1: Distribution of study parameters

\begin{tabular}{lc}
\hline Age & $\begin{array}{c}\mathrm{n}, \text { Mean } \pm \text { SD } \\
\text { or } \% \\
45.16 \pm 10.12 \\
\text { Follow-up period }\end{array}$ \\
BMI at the time of operation $\left(\mathrm{kg} / \mathrm{m}^{2}\right)$ & $49.68 \pm 7.91$ \\
BMI during measurement $\left(\mathrm{kg} / \mathrm{m}^{2}\right)$ & $33.06 \pm 6.95$ \\
BMI at the time of operation & \\
$<50$ & $33,54.1 \%$ \\
$\geq 50$ & $28,45.9 \%$ \\
Asymptomatic TSH & $5,8.2 \%$ \\
Symptomatic TSH & $2,3.3 \%$ \\
TSH development status & \\
No & $54,88.5 \%$ \\
Yes & $7,11.5 \%$ \\
Hernia region ( $=7)$ & \\
Upper right quadrant & $1,14.3 \%$ \\
Supraumbilical & $6,85.7 \%$ \\
\hline
\end{tabular}

BMI: Body mass index, TSH: Trocar site herni

The follow-up period of the patients included in the study ranged from 20 to 52 months, with a mean of $39.2 \pm 7.91$ and a median of 36 .

The BMI values of the patients at the time of operation ranged from 36.85 to 69.06 , with a mean of $49.68 \pm 6.35$. The BMI values during measurement ranged from 17.42 to 48.49 and the mean value was calculated as $33.06 \pm 6.95$.

During TSH evaluation, no TSH was detected in $96.7 \%$ of the patients upon physical examination at rest and Valsalva position, while it was detected in $3.3 \%$ of them upon 
Table 2: Evaluation of study parameters in terms of TSH development status

\begin{tabular}{|c|c|c|c|}
\hline & \multicolumn{2}{|c|}{ TSH development status } & \multirow[b]{3}{*}{$\mathbf{p}$} \\
\hline & No & Yes & \\
\hline & Mean $\pm S D$ & Mean $\pm S D$ & \\
\hline Age & $44.24 \pm 10.16$ & $52.29 \pm 6.87$ & ${ }^{1} 0.047^{*}$ \\
\hline Follow-up period & $\begin{array}{c}38.76 \pm 7.99 \\
(36)\end{array}$ & $\begin{array}{c}42.57 \pm 6.8 \\
(45)\end{array}$ & ${ }^{2} 0.364$ \\
\hline Weight at the time of operation & $131.87 \pm 20.09$ & $132.86 \pm 12.32$ & ${ }^{1} 0.900$ \\
\hline Weight during TSH evaluation & $85.2 \pm 17.29$ & $107.43 \pm 20.1$ & ${ }^{1} 0.003^{*}$ \\
\hline $\mathrm{BMI}$ at the time of operation & $49.33 \pm 6.58$ & $52.4 \pm 3.35$ & ${ }^{1} 0.231$ \\
\hline BMI during TSH evaluation & $31.85 \pm 5.91$ & $42.43 \pm 7.69$ & ${ }^{1} 0.000 *$ \\
\hline \multirow[t]{2}{*}{ BMI difference } & $17.48 \pm 5.55$ & $9.97 \pm 7.61$ & ${ }^{1} 0.002^{\star}$ \\
\hline & n (\%) & n (\%) & \\
\hline Asymptomatic & $54(100 \%)$ & $5(71.4 \%)$ & ${ }^{3} 0.011^{\star}$ \\
\hline Symptomatic & $0(0 \%)$ & 2 (28.6\%) & \\
\hline \multicolumn{4}{|l|}{ Diabetes mellitus } \\
\hline Yes & $6(11 \%)$ & 2 (29\%) & ${ }^{3} 0.225^{\star}$ \\
\hline No & 48 (89\%) & $5(71 \%)$ & \\
\hline
\end{tabular}

': Student t-test, ${ }^{2}$ : Mann Whitney $U$ test, ${ }^{3}$ : Fisher's exact test, ${ }^{*}: \mathrm{p}<0.05$ BMI: Body mass index, TSH: Trocar site hernia

physical examination. Of the patients with hernia, $14.3 \%$ had TSH in the right upper quadrant and $85.7 \%$ in the supraumbilical trocar site.

The incidence of TSH was found to be significantly lower in the patients with adequate weight loss compared to those without adequate weight loss after operation $(p<0.05)$ (Table 2).

\section{DISCUSSION}

In our study, despite the repair of all fascial defects of $10 \mathrm{~mm}$ or more after LSG procedure, we determined the rate of development of symptomatic (detected upon physical examination) and asymptomatic (not detected upon physical examination, can only be revealed in superficial USG) TSH as $11.5 \%$. Among these cases, the rate of symptomatic TSH was only 3.3\%. Asymptomatic TSH, which could not be detected upon physical examination, was detected in $8.2 \%$ of the patients.

In the literature, the incidence of TSH was reported to be between $0.23 \%$ and $3.1 \%$ in the general population (8). This rate was found to be higher in obese patients. In correlation with this, the incidence of TSH was found to be higher in our study.

The incidence of incisional hernia development in obese patients with higher BMI rates was found to be increased by Uslu et al. (9). However, there are no studies in the lit- erature with a high level of evidence that can clearly show the incidence of trocar site hernia in obese patients. In our study, this rate was found to be $11.5 \%$. In this study, while the frequency of symptomatic TSH was found to be consistent with the literature, we found that this frequency increased in superficial USG applied to asymptomatic patients. We found that TSH was more common in patients who could not lose weight after bariatric surgery. We think that the reason for the higher TSH frequency in this study compared to the literature is due to the high number of patients who could not achieve adequate weight loss among the patients included in the study.

Iranmanesh et al. were able to reach 23 of 70 patients who underwent bariatric surgery and in whose operation the CTSP and NeoClose suture passer were used as fascia closure devices at the one-year follow-up in their study. They did not encounter any TSH upon physical examination and abdominal ultrasonography during the one-year follow-up of these 23 patients. Considering this situation, we thought that the incidence of TSH increased as the follow-up period was prolonged (10).

In the literature, weight loss failure was described as $<50 \%$ Excess Weight Loss (EWL) postoperatively, less than $20 \%$ loss of preoperative total body weight, and BMI above 35 $\mathrm{kg} / \mathrm{m}^{2}(11)$. In our study, the group described as unable to lose weight was formed in light of this information. 
Full-thickness closure of all anatomical walls is very difficult in the obese patient group. Hand-assisted closure is often not successful and also causes time loss (12). The use of new laparoscopic trocar site closure techniques instead of the traditional hand-assisted fascia closure technique enables the peritoneal and fascial leaves to be closed together. At the same time, the repair of trocar site defects in obese patients can be performed in a much safer and easier way thanks to new laparoscopic trocar site closure techniques (13).

Many risk factors have been identified in the development of incisional hernia or TSH. Some of those are advanced age, gender (male>female), nutritional status, diabetes, anemia, steroid treatment, renal failure, cancer, and wound infections (14). We found that the frequency of TSH development was higher in advanced age patients in our study. At the same time, we thought that the frequency of TSH development was higher in patients with less postoperative weight loss due to higher intraabdominal pressure.

In the literature, it is recommended to close the fascial defects of the trocars with a thickness of $10 \mathrm{~mm}$ and more as the risk of developing TSH is high $(15,16)$. Contrary to this information, in our study, we found that a patient developed hernia from a 5-mm trocar area. In the study group where we evaluated a small number of cases, it was not possible to make any further assumptions about 5-mm trocar site hernia. However, randomized studies with a higher number of patients should investigate the factors that affect the risk of hernia in these areas.

\section{BIAS}

Some of the most important drawbacks of this study are that it was not prospectively designed, the number of the patients was relatively low, and the procedures were performed by more than one general surgeon.

In the literature, there is no clear ratio showing the incidence of TSH development after LSG procedure in morbidly obese patients.

\section{CONCLUSION}

In patients who did not lose enough weight after laparoscopic sleeve gastrectomy and in elderly patients, the rate of development of trocar site hernia is higher and most of these patients are asymptomatic. In these patients, physical examination is not successful in the evaluation of trocar site hernia and superficial USG is recommended.

Informed Consent: Written consent was obtained from the participants.

Ethics Committee Approval: This study was approved by the Clinical Research Ethical Committee of the Health Sciences Uni- versity, Istanbul Fatih Sultan Mehmet Training and Research Hospital (Date: 12.09.2019, No: 80).

Peer Review: Externally peer-reviewed.

Author Contributions: Conception/Design of Study- A.E., H.Ç., A.B.K., K.M.; Data Acquisition- A.E., M.M.F., I.T.; Data Analysis/ Interpretation- N.E.B., A.Y.I., Y.G.; Drafting Manuscript- A.E., H.Ç., A.B.K., Y.G., K.M.; Critical Revision of Manuscript- M.M.F., N.E.B., A.Y.I., I.T.; Approval and Accountability- A.E., M.M.F., N.E.B., A.B.K., Y.i., H.Ç., Y.G., I.T., K.M.

Conflict of Interest: Authors declared no conflict of interest

Financial Disclosure: Authors declared no financial support.

\section{REFERENCES}

1. Ahmad G, Duffy JM, Phillips K, Watson A. Laparoscopic entry techniques. Cochrane Database Syst Rev 2008;(2):CD006583. [CrossRef]

2. Jansen FW, Kolkman W, Bakkum EA, de Kroon CD, TrimbosKemper TC, Trimbos JB. Complications of laparoscopy: An inquiry about closed- versus open-entry technique. Am J Obstet Gynecol 2004;190(3):634-8. [CrossRef]

3. Azziz R, Murphy AA. Practical Manual of operative Laparoscopy and hysteroscopy. New York: Springer-Verlag; 1992. pp. 1-8. [CrossRef]

4. Shah PR, Naguib N, Thippeswammy K, Masoud AG. Port site closure after laparoscopic surgery. J Minim Access Surg 2010;6(1):22-3. [CrossRef]

5. Botea F, Torzilli G, Sarbu V. A simple, effective technique for port-site closure after laparoscopy. JSLS 2011;15(1):77-80. [CrossRef]

6. Bonatti H, Hoeller E, Kirchmayr W, Muhlmann G, Zitt M, Aigner $F$, et al. Ventral hernia repair in bariatric surgery. Obes Surg 2004;14(5):655-8. [CrossRef]

7. Fuller J, Ashar BS, Carey-Corrado J. Trocar-associated injuries and fatalities: An analysis of 1399 reports to the FDA. J Minim Invasive Gynecol 2005;12(4):302-7. [CrossRef]

8. Kadar N, Reich H, Liu CY, Manko GF, Gimpelson R. Incisional hernias after major laparoscopic gynecological procedures. Am J Obstet Gynecol 1993;168(5):1493-5. [CrossRef]

9. Mendoza D, Newman RC, Albala D, Cohen MS, Tewari A, Lingeman J, et al. Laparoscopic complications in markedly obese urologic patients (a multi-institutional review). Urology 1996;48(4):562-7. [CrossRef]

10. Iranmanesh $P$, Rivera AR, Bajwa KS, Alibhai M, Snyder $B E$, Wilson $T D$, et al. Trocar site closure with a novel anchor-based (neoClose ${ }^{\circledR}$ ) system versus standard suture closure: a prospective randomized controlled trial. Surg Endosc 2020;34(3):1270-6. [CrossRef]

11. Sjöström $L$, Lindroos $A K$, Peltonen $M$, Torgerson J, Bouchard C, Carlsson B, et al. Lifestyle, diabetes, and cardiovascular risk factors 10 years after bariatric surgery. N Engl J Med 2004;351(26):2683-93. [CrossRef]

12. Eid GM, Collins J. Application of a trocar wound closure system designed for laparoscopic procedures in morbidly obese patients. Obes Surg 2005;15(6):871-3. [CrossRef] 
13. Nakada SY, McDougall EM, Gardner SM, Gonzalez G, Clayman RV. Comparison of newer laparoscopic port closure techniques in the porcine model. J Endourol 1995;9(5):397-401. [CrossRef]

14. Pamela D, Roberto C, Francesco LM, Umberto M, Carla $M$, Vincenzo $N$, et al. Trocar site hernia after laparoscopic colectomy: a case report and literature review. ISRN Surg 2011;2011:725601. [CrossRef]
15. Helgstrand F, Rosenberg J, Bisgaard T. Trocar site hernia after laparoscopic surgery: a qualitative systematic review. Hernia 2011;15(2):113-21. [CrossRef]

16. Ng WT. A full review of port-closure techniques. Surg Endosc 2007;21(10):1895-7. [CrossRef] 